\title{
Backbone ${ }^{1} \mathrm{H},{ }^{13} \mathrm{C}$, and ${ }^{15} \mathrm{~N}$ resonance assignments of the $\mathrm{Fc}$ fragment of human immunoglobulin $G$ glycoprotein
}

\author{
Hirokazu Yagi $\cdot$ Ying Zhang $\cdot$ Maho Yagi-Utsumi • \\ Takumi Yamaguchi · Shigeru Iida • \\ Yoshiki Yamaguchi $\cdot$ Koichi Kato
}

Received: 16 September 2014/ Accepted: 30 September 2014/Published online: 8 October 2014

(c) The Author(s) 2014. This article is published with open access at Springerlink.com

\begin{abstract}
The Fc portion of immunoglobulin G (IgG) recruits complements and its cognate receptors, thereby promoting defensive mechanisms in the humoral immune system. These effector functions critically depend on $\mathrm{N}$ glycosylation at the $\mathrm{Fc}$ region, which is therefore regarded as a crucial factor in the design and production of therapeutic antibodies. NMR spectroscopy plays a unique role in the characterization of conformational dynamics and intermolecular interactions of IgG-Fc in solutions. Here, we report NMR assignments of the glycosylated Fc fragment $(M \mathrm{r} 53 \mathrm{kDa})$, cleaved from a chimeric antibody with human IgG1 constant regions, which was produced in
\end{abstract}

Hirokazu Yagi and Ying Zhang have contributed equally to this work.

Electronic supplementary material The online version of this article (doi:10.1007/s12104-014-9586-7) contains supplementary material, which is available to authorized users.

H. Yagi · Y. Zhang · M. Yagi-Utsumi · T. Yamaguchi ·

Y. Yamaguchi $\cdot$ K. Kato

Graduate School and Faculty of Pharmaceutical Sciences,

Nagoya City University, Nagoya 467-8603, Japan

Y. Zhang · M. Yagi-Utsumi - T. Yamaguchi · K. Kato $(\bowtie)$

Okazaki Institute for Integrative Bioscience and Institute for

Molecular Science, National Institutes of Natural Sciences,

Okazaki, Aichi 444-8787, Japan

e-mail: kkato@phar.nagoya-cu.ac.jp

S. Iida

Kyowa Hakko Kirin, Co., Ltd., Chiyoda-ku, Tokyo 100-0004, Japan

\section{Y. Yamaguchi}

Structural Glycobiology Team, Systems Glycobiology Research

Group, RIKEN-Max Planck Joint Research Center, RIKEN

Global Research Cluster, 2-1 Hirosawa, Wako,

Saitama 351-0198, Japan
Chinese hamster ovary cells with uniform ${ }^{13} \mathrm{C}$ - and ${ }^{15} \mathrm{~N}$ labeling.

Keywords Immunoglobulin G · Fc · Glycoprotein · Mammalian expression system · NMR spectroscopy · Resonance assignment

\section{Biological context}

Immunoglobulin $\mathrm{G}(\mathrm{IgG})$ is a multifunctional glycoprotein composed of an Fc region and two Fab regions, which are connected through the hinge region (Yamaguchi et al. 2007). The Fab regions recognize and capture specific antigens, while the $\mathrm{Fc}$ region recruits complements and its cognate receptors, $\mathrm{F} c \gamma$ receptors ( $\mathrm{F} \gamma \mathrm{Rs}$ ), and offers acceptor sites for bacterial proteins including protein $\mathrm{A}$ and protein $\mathrm{G}$. The $\mathrm{Fc}$ region has a homodimeric structure comprising the $\mathrm{C}$-terminal halves of the heavy chains, each composed of the $\mathrm{C}_{\mathrm{H}} 2$ and $\mathrm{C}_{\mathrm{H}} 3$ domains. The $\mathrm{C}_{\mathrm{H}} 2$ domain possesses a conserved $\mathrm{N}$-glycosylation site, Asn297, at which a biantennary complex-type oligosaccharide is expressed with microheterogenieties characterized by the presence and absence of the non-reducing terminal galactose, fucose, sialic acid, and bisecting $N$-acetylglucosamine residues.

The effector function of IgG critically depends on $\mathrm{N}$ glycosylation in the $\mathrm{Fc}$ region. The outer carbohydrate moieties govern the structural integrity of the Fc $\gamma \mathrm{R}$-binding site of $\mathrm{IgG}$, while the core fucosylation impairs antibody-dependent cellular cytotoxicity because of its negative steric effect against IgG interaction with Fc $\gamma$ RIII (Ferrara et al. 2011; Krapp et al. 2003; Mizushima et al. 2011; Yamaguchi et al. 2006). Hence, the Fc glycoforms are now considered as a crucial factor in the design and 
production of therapeutic antibodies in biopharmaceutical fields (Berkowitz et al. 2012; Jiang et al. 2011).

NMR spectroscopy offers unique tools for characterizing the conformational dynamics and intermolecular interactions of IgG-Fc in solution (Kato et al. 1991a, 1993a, 1995; Kim et al. 1994a; Latypov et al. 2012). We developed protocols for uniform and amino acid-selective stable isotope labeling of an $\mathrm{IgG}$ glycoprotein and its functional fragments, using mammalian expression systems (Kato et al. 2010; Yamaguchi and Kato 2010). Based on partially (approximately 66\%) achieved spectral assignments (Yamaguchi et al. 2006), we previously reported NMR analytical results to characterize the $N$ glycosylation-dependent conformational changes of human IgG1-Fc and its interaction with a specific RNA aptamer (Matsumiya et al. 2007; Miyakawa et al. 2008; Yamaguchi et al. 2006).

In an extension of these studies, we herein report NMR assignments of the glycosylated version of Fc fragment $(\mathrm{Mr}$ $53 \mathrm{kDa}$ ) cleaved from a chimeric antibody with human IgG1 constant regions that was expressed by Chinese hamster ovary $(\mathrm{CHO})$ cells with uniform ${ }^{13} \mathrm{C}$ - and ${ }^{15} \mathrm{~N}$ labeling.

\section{Methods and experiments}

The CHO/DG44 cell line (Urlaub1980) was kindly provided by Dr. Lawrence Chasin (Columbia University, NY). An anti-CCR4 chimeric antibody (designated KM3060), with human $\mathrm{IgG} 1 / \kappa$ constant regions, was produced in a $\mathrm{CHO}$ cell line as described previously (Yamaguchi and Kato 2010; Yamaguchi et al. 2006). The CHO cells were cultivated using the Nissui NYSF 404 medium supplemented with $2 \%$ dialyzed fetal bovine serum. At the final stage of cell culture, the medium was replaced with an isotopically labeled one with $2 \%$ dialyzed fetal bovine serum. Uniformly ${ }^{15} \mathrm{~N} /{ }^{13} \mathrm{C}$ labeled IgG1 was prepared using a modified Nissui NYSF 404 medium (supplemented with $2 \%$ dialyzed fetal bovine serum) in which glucose, sodium pyruvate, succinic acid, and amino acids were replaced by $1 \mathrm{~g} / \mathrm{L}\left[{ }^{15} \mathrm{~N} /{ }^{13} \mathrm{C}\right]$ algal amino acid mixture, $2 \mathrm{~g} / \mathrm{L} \mathrm{D}-\left[{ }^{13} \mathrm{C}_{6}\right]$ glucose, $110 \mathrm{mg} / \mathrm{L}\left[{ }^{13-}\right.$ $\mathrm{C}_{3}$ ]pyruvic acid sodium salt, $59 \mathrm{mg} / \mathrm{L}\left[{ }^{13} \mathrm{C}_{4}\right]$ succinic acid, $149 \mathrm{mg} / \mathrm{L} \quad \mathrm{L}-\left[{ }^{13} \mathrm{C}_{6},{ }^{15} \mathrm{~N}_{4}\right] \mathrm{Arg} \cdot \mathrm{HCl}, 42.5 \mathrm{mg} / \mathrm{L} \mathrm{L}-\left[{ }^{13} \mathrm{C}_{4},{ }^{15-}\right.$ $\left.\mathrm{N}_{2}\right]$ Asn $\cdot \mathrm{H}_{2} \mathrm{O}, 24 \mathrm{mg} / \mathrm{L} \mathrm{L}-\left[{ }^{13} \mathrm{C}_{3},{ }^{15} \mathrm{~N}\right] \mathrm{Cys}, 450 \mathrm{mg} / \mathrm{L} \mathrm{L}-\left[{ }^{13-}\right.$ $\left.\mathrm{C}_{5},{ }^{15} \mathrm{~N}_{2}\right] \mathrm{Gln}, 17 \mathrm{mg} / \mathrm{L} \mathrm{L}-\left[{ }^{13} \mathrm{C}_{6},{ }^{15} \mathrm{~N}_{3}\right] \mathrm{His} \cdot \mathrm{HCl} \cdot \mathrm{H}_{2} \mathrm{O}, 27 \mathrm{mg} / \mathrm{L}$ $\mathrm{L}-\left[{ }^{13} \mathrm{C}_{9},{ }^{15} \mathrm{~N}\right] \mathrm{Tyr}$, and $7 \mathrm{mg} / \mathrm{L} \mathrm{L}-\left[{ }^{13} \mathrm{C}_{11},{ }^{15} \mathrm{~N}_{2}\right] \mathrm{Trp}$. Amino acid-selective labeling of IgG1 was performed using the modified Nissui NYSF 404 medium (supplemented with $2 \%$ dialyzed fetal bovine serum) in which selected amino acid components were substituted with isotopically labeled analogs, as described previously (Kato et al. 1991a, b, 1993b; Kim et al. 1994b). After cell growth, the supernatant was purified using an Affi-gel protein A column (GE Healthcare Bio-Sciences), as described previously (Yamaguchi et al. 1995). The Fc fragment of IgG1 was prepared by papain digestion, performed at $37{ }^{\circ} \mathrm{C}$ for $12 \mathrm{~h}$ in $75 \mathrm{mM}$ sodium phosphate buffer ( $\mathrm{pH} 7.0$ ) containing $75 \mathrm{mM} \mathrm{NaCl}$, and $2 \mathrm{mM}$ EDTA. The protein concentration was $10 \mathrm{mg} / \mathrm{ml}$, and the ratio of papain/IgG1 was 1:50 (w:w). The digestion products were loaded onto an Affi-gel protein A column. To prepare IgG1-Fc exhibiting a homogeneous $N$-glycan, GlcNAc $\beta 1$-2Man $\alpha 1$-3(GlcNAc $\beta 1$-2Man $\alpha 1-6)$ Man $\beta 1-4 G l c-$ NAc $\beta 1-4($ Fuc $\alpha 1-6)$ GlcNAc, the Fc fragment was treated with a recombinant Streptococcus pneumoniae $\beta 1,4$-galactosidase (CALBIOCHEM), according to the literature (Yamaguchi et al. 2006).

For NMR measurements, the Fc fragment was dissolved in $0.5 \mathrm{ml}$ of $5 \mathrm{mM}$ sodium phosphate buffer ( $\mathrm{pH}$ 6.0) containing $50 \mathrm{mM} \mathrm{NaCl}$ and $10 \%(\mathrm{v} / \mathrm{v}) \mathrm{D}_{2} \mathrm{O}$. NMR spectra were acquired at 42 or $52{ }^{\circ} \mathrm{C}$ using DMX500 (Bruker BioSpin), AVANCE800 (Bruker BioSpin), and ECA-920 (JEOL) spectrometers. Chemical shifts of ${ }^{1} \mathrm{H}$ were referenced to DSS (0 ppm), and ${ }^{13} \mathrm{C}$ and ${ }^{15} \mathrm{~N}$ chemical shifts were referenced indirectly using the gyromagnetic ratios of ${ }^{13} \mathrm{C},{ }^{15} \mathrm{~N}$, and ${ }^{1} \mathrm{H}$ $\left(\gamma^{13} \mathrm{C} / \gamma^{1} \mathrm{H}=0.25144952 ; \gamma^{15} \mathrm{~N} / \gamma^{1} \mathrm{H}=0.10132905\right)$.

Backbone resonance assignments were made on the basis of $2 \mathrm{D}{ }^{1} \mathrm{H}-{ }^{15} \mathrm{~N}$ HSQC spectral data of uniformly or selectively ${ }^{13} \mathrm{C} /{ }^{15} \mathrm{~N}$-labeled $\mathrm{IgG} 1-\mathrm{Fc}$, and $3 \mathrm{D}$ spectral data obtained with the following experiments: HNCA, HNCO, $\mathrm{HN}(\mathrm{CA}) \mathrm{CO}, \mathrm{CBCA}(\mathrm{CO}) \mathrm{NH}$, and HNCACB. All NMR data were processed using NMRPipe software (Delaglio et al. 1995), and analyzed with SPARKY (Goddard and Kneller 1993) and CcpNmr (Vranken et al. 2005) software.

\section{Assignments and data deposition}

Figure 1 shows the ${ }^{1} \mathrm{H}-{ }^{15} \mathrm{~N}$ HSQC spectrum of human IgG1-Fc. Although the use of a mammalian expression system is mandatory for preparing antibodies with physiological glycosylation, uniform deuteration of the glycoprotein is not facile in such a system (Liu et al. 2007). Hence, we established spectral assignments based on the triple resonance spectral dataset recorded at a higher temperature, i.e. $52{ }^{\circ} \mathrm{C}$, complemented with HSQC spectral data obtained by amino acid-selective ${ }^{13} \mathrm{C} /{ }^{15} \mathrm{~N}$-labeling. Chemical shift assignments were made for protein backbone resonances: $\mathrm{C} \alpha(99 \%), \mathrm{C} \beta(84 \%), \mathrm{CO}(80 \%), \mathrm{HN}$ (99\%), and $\mathrm{N}(99 \%)$ (except for $\mathrm{N}$ of prolines). The spectral assignments at lower temperatures could be extrapolated by observing progressive spectral changes, depending on temperature, as exemplified by the spectrum at $42{ }^{\circ} \mathrm{C}$ (Supplemental Fig.1). The present spectral assignments indicate that a cluster of amino acid residues in the vicinity of the $N$-glycans, i.e. Gln295-Thr299 exhibit 


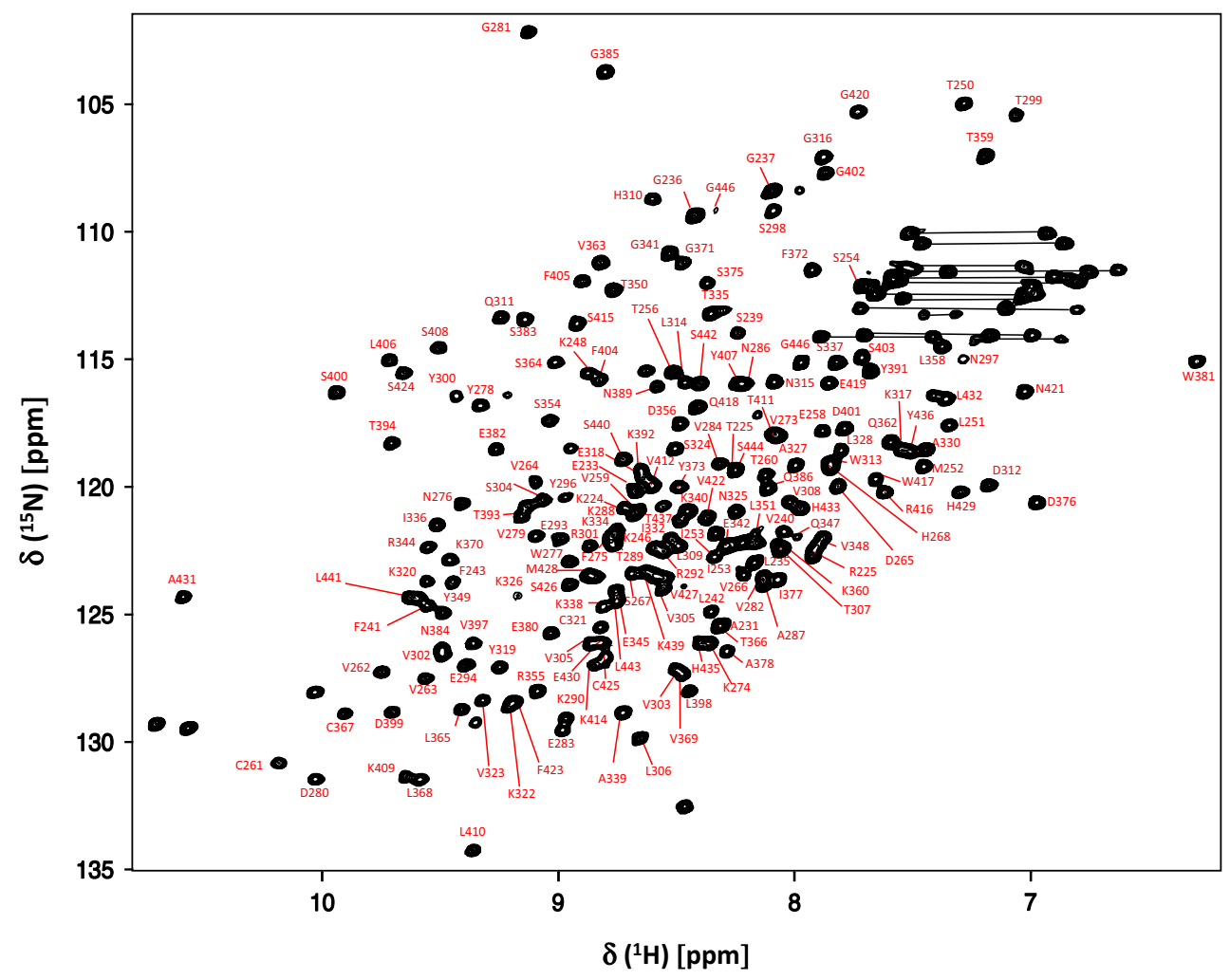

Fig. $1{ }^{1} \mathrm{H}-{ }^{15} \mathrm{~N}$ HSQC spectrum of uniformly ${ }^{13} \mathrm{C},{ }^{15} \mathrm{~N}$-labeled IgG$\mathrm{Fc}$ recorded at $52{ }^{\circ} \mathrm{C}$. Backbone assignments are annotated by the resonance peaks with one-letter amino acid codes and the sequence

significant chemical shift differences in comparison with the previously reported assignments of human $\mathrm{Fc}$ produced in Escherichia coli (Liu et al. 2007).

The assignments for the ${ }^{1} \mathrm{H},{ }^{13} \mathrm{C}$, and ${ }^{15} \mathrm{~N}$ backbone resonances of human IgG1-Fc have been deposited in the BioMagResBank database (http://www.bmrb.wisc.edu) under the accession number 25224.

Acknowledgments We would like to thank Ms. Kumiko Hattori and Ms. Kiyomi Senda (Nagoya City University) for their help with recombinant protein preparation. This work was supported, in part, by the Nanotechnology Platform Project, the Program for the Promotion of Fundamental Studies in Health Sciences of the National Institute of Biomedical Innovation (NIBIO), and Grants-in-Aid for Scientific Research (24249002 and 25860053) from the Ministry of Education, Culture, Sports, Science and Technology (MEXT).

Open Access This article is distributed under the terms of the Creative Commons Attribution License which permits any use, distribution, and reproduction in any medium, provided the original author(s) and the source are credited.

\section{References}

Berkowitz SA, Engen JR, Mazzeo JR, Jones GB (2012) Analytical tools for characterizing biopharmaceuticals and the implications for biosimilars. Nat Rev Drug Discov 11:527-540 numbers. Side-chain resonances corresponding to $\mathrm{NH}_{2}$ amides are connected by horizontal lines

Delaglio F, Grzesiek S, Vuister GW, Zhu G, Pfeifer J, Bax A (1995) NMRPipe: a multidimensional spectral processing system based on UNIX pipes. J Biomol NMR 6:277-293

Ferrara C, Grau S, Jäger C, Sondermann P, Brünke P, Waldhauer I, Hennig M, Ruf A, Rufer AC, Stihle M, Umaña P, Benz J (2011) Unique carbohydrate-carbohydrate interactions are required for high affinity binding between Fc $\gamma \mathrm{RIII}$ and antibodies lacking core fucose. Proc Natl Acad Sci USA 108:12669-12674

Goddard T, Kneller D (1993) SPARKY 3. University of California, San Francisco

Jiang XR, Song A, Bergelson S, Arroll T, Parekh B, May K, Chung S, Strouse R, Mire-Sluis A, Schenerman M (2011) Advances in the assessment and control of the effector functions of therapeutic antibodies. Nat Rev Drug Discov 10:101-111

Kato K, Matsunaga C, Igarashi T, Kim H, Odaka A, Shimada I, Arata Y (1991a) Complete assignment of the methionyl carbonyl carbon resonances in switch variant anti-dansyl antibodies labeled with $\left[1{ }^{13} \mathrm{C}\right]$ methionine. Biochemistry 30:270-278

Kato K, Matsunaga C, Odaka A, Yamato S, Takaha W, Shimada I, Arata Y (1991b) Carbon-13 NMR study of switch variant antidansyl antibodies: antigen binding and domain-domain interactions. Biochemistry 30:6604-6610

Kato K, Gouda H, Takaha W, Yoshino A, Matsunaga C, Arata Y (1993a) ${ }^{13} \mathrm{C}$ NMR study of the mode of interaction in solution of the B fragment of staphylococcal protein $\mathrm{A}$ and the $\mathrm{Fc}$ fragments of mouse immunoglobulin G. FEBS Lett 328:49-54

Kato K, Gouda H, Takaha W, Yoshino A, Matsunaga C, Arata Y (1993b) ${ }^{13} \mathrm{C}$ NMR study of the mode of interaction in solution of the $\mathrm{B}$ fragment of staphylococcal protein $\mathrm{A}$ and the $\mathrm{Fc}$ fragments of mouse immunoglobulin G. FEBS Lett 328:49-54 
Kato K, Lian LY, Barsukov IL, Derrick JP, Kim H, Tanaka R, Yoshino A, Shiraishi M, Shimada I, Arata Y et al (1995) Model for the complex between protein $\mathrm{G}$ and an antibody Fc fragment in solution. Structure 3:79-85

Kato K, Yamaguchi Y, Arata Y (2010) Stable-isotope-assisted NMR approaches to glycoproteins using immunoglobulin $\mathrm{G}$ as a model system. Prog Nucl Magn Reson Spectrosc 56:346-359

Kim H, Matsunaga C, Yoshino A, Kato K, Arata Y (1994a) Dynamical structure of the hinge region of immunoglobulin $G$ as studied by ${ }^{13} \mathrm{C}$ nuclear magnetic resonance spectroscopy. J Mol Biol 236:300-309

Kim H, Matsunaga C, Yoshino A, Kato K, Arata Y (1994b) Dynamical structure of the hinge region of immunoglobulin $G$ as studied by ${ }^{13} \mathrm{C}$ nuclear magnetic resonance spectroscopy. J Mol Biol 236:300-309

Krapp S, Mimura Y, Jefferis R, Huber R, Sondermann P (2003) Structural analysis of human IgG-Fc glycoforms reveals a correlation between glycosylation and structural integrity. J Mol Biol 325:979-989

Latypov RF, Hogan S, Lau H, Gadgil H, Liu D (2012) Elucidation of acid-induced unfolding and aggregation of human immunoglobulin IgG1 and IgG2 Fc. J Biol Chem 287:1381-1396

Liu D, Cocco MJ, Rosenfied R, Lewis JK, Ren D, Li L, Remmele RL Jr, Brems DN (2007) Assignment of backbone ${ }^{1} \mathrm{H},{ }^{13} \mathrm{C}$ and ${ }^{15} \mathrm{~N}$ resonances of human IgG1 Fc (51.4 kDa). Biomol NMR Assign 1:233-235

Matsumiya S, Yamaguchi Y, Saito J, Nagano M, Sasakawa H, Otaki S, Satoh M, Shitara K, Kato K (2007) Structural comparison of fucosylated and nonfucosylated Fc fragments of human immunoglobulin G1. J Mol Biol 368:767-779
Miyakawa S, Nomura Y, Sakamoto T, Yamaguchi Y, Kato K, Yamazaki S, Nakamura Y (2008) Structural and molecular basis for hyperspecificity of RNA aptamer to human immunoglobulin G. RNA 14:1154-1163

Mizushima T, Yagi H, Takemoto E, Shibata-Koyama M, Isoda Y, Iida S, Masuda K, Satoh M, Kato K (2011) Structural basis for improved efficacy of therapeutic antibodies upon defucosylation of their Fc glycans. Genes Cells 16:1071-1080

Vranken WF, Boucher W, Stevens TJ, Fogh RH, Pajon A, Llinas M, Ulrich EL, Markley JL, Ionides J, Laue ED (2005) The CCPN data model for NMR spectroscopy: development of a software pipeline. Proteins 59:687-696

Yamaguchi Y, Kato K (2010) Dynamics and interactions of glycoconjugates probed by stable-isotope-assisted NMR spectroscopy. Methods Enzymol 478:305-322

Yamaguchi Y, Kim H, Kato K, Masuda K, Shimada I, Arata Y (1995) Proteolytic fragmentation with high specificity of mouse immunoglobulin G. Mapping of proteolytic cleavage sites in the hinge region. J Immunol Methods 181:259-267

Yamaguchi Y, Nishimura M, Nagano M, Yagi H, Sasakawa H, Uchida K, Shitara K, Kato K (2006) Glycoform-dependent conformational alteration of the $\mathrm{Fc}$ region of human immunoglobulin G1 as revealed by NMR spectroscopy. Biochim Biophys Acta 1760:693-700

Yamaguchi Y, Takahashi N, Kato K (2007) Antibody Strucutres. In: Kamerling JP (ed) Comprehensive glycoscience, vol 3. Elsevier, Oxford, pp 745-763 